\title{
Sangkal Putung, As Perceived By People With Musculoskeletal Fracture
}

\author{
Ira Suarilah \\ Faculty of Nursing Universitas Airlangga \\ Surabaya, Indonesia \\ ira.suarilah@fkp.unair.ac.id \\ Candra Panji Asmoro \\ Faculty of Nursing Universitas Airlangga \\ Surabaya, Indonesia
}

\author{
Andri Setya Wahyudi \\ Faculty of Nursing Universitas Airlangga \\ Surabaya, Indonesia
}

\begin{abstract}
In Indonesia, traditional healing, as it is known as Sangkal Putung (SP) has been an alternative for fracture treatment. People with fracture at any age, anywhere and any case went to SP even there was a general hospital with surgery service. SP, where was the study taken is located in rural area where is approximately $40 \mathrm{~km}$ from Surabaya, the capital city of East Java Province. The study aimed to explore patient's experience of fracture healing at SP. The method and methodology were Hermeneutic Phenomenological study that used deep interviews. The participant was taken by purposive sampling, adult aged 25 to 55 -years old and were at the second or more of healing series. Data originated from seven participants and 13 interviews. Interviews were recorded, transcribed verbatim and analysis. The findings showed that previous close friends, relatives and family's experience of SP were the main issued of decision-making process. Participants with several SP experience had different views of SP; they seemed that SP today is more convenient than before. Most of them stated that safety and comfort was the priority for the fracture healing. The concept of culture in the behavioral alteration of fracture healing can have on the participants.
\end{abstract}

Keywords: fracture, traditional healing, sangkal putung, transcultural nursing

\section{INTRODUCTION}

In general, fractures caused by trauma or physical exertion muscle and angle of the muscle. The state of the bone and the soft tissues around the bone will determine whether the fracture was complete or incomplete [1-3].

The most common cause of fracture in Indonesia is accident. Accordingly, traffic accident is one of the priorities of non-communicable disease control based Kepmenkes 116 / Menkes / SK / VIII / 2003. Analysis of public health data on injuries caused by traffic accidents from 33 provinces in Indonesia in 2012 showed that the proportion of fracture and or limb injuries was about $9.1 \%$ [4].

According to [5] almost $80 \%$ of Indonesian actually chooses alternative healing to treat any diseases they experienced, and only $20 \%$ of them applied conventional healing that is hospital services.

Alternative healing on fracture can be reached both medically and non-medically. One more non-medical fracture developed in the community is disclaimed SP. People who take the treatment of fractures in nonmedical have been many, but the background which causes the sufferer fracture treatment to SP cannot be explained.

SP is a traditional healing of fractures by herbalists fractures who are considered to have supernatural powers by way of massaging, giving prayers and oil [6]. While in the other country, a traditional healer is a person who is believed by its community to provide healthcare by using certain method such as herbs, animal, and mineral substances based on social, cultural, and religious principle in their community [7]. The process of fracture healing is affected by several factors such as age, location, severity of fractures, a shift that occurs in the bone, vascularization of the bone fracture, reduction and immobilization, duration of immobilization, infection and active movement or passive limb and knowledge of patients in both the treatment [8].

Indonesian prefers traditional healing compared to the hospital or doctor. Data from the National Health Survey 2001 by the Ministry of Health pointed out that $31.7 \%$ of people use traditional healing are $9.8 \%$ of people seeking treatment in the traditional way to deal with a health issue to go to shamans, healers and so on. People who treat with modern healing and traditional healing are as much as $57.7 \%$ [5].

For those written above, an exploration on the perception of people with fractures to traditional healing in SP is essential due to the development basic nursing needs on safety and comfort as well as cross-cultural nursing effect on behavioral alteration of healing of patients with fracture. 


\section{MethODS}

\section{A. Design}

The method and methodology were Hermeneutic Phenomenological study that applied deep interviews. This methodology enables researcher to explore the phenomena [9] of people with fracture who decide to go to SP for fracture healing. This can be identified through clinical nursing problems and ask researchable questions [10]. Similarly, (9) suggest a personal interest can become the driving force needed to formulate a research question. To some extent, practitioners will then need to identify and develop an interest in a potential change in practice issue, which is usually stimulated by patient preferences and dissatisfaction, quality improvement data, practitioner queries, evaluation data or new research data [11].

For this study, the participant were taken by purposive sampling, adult aged 25 to 55-years old and were at the second or more of healing series visiting. Data originated from seven participants and 13 interviews. Interviews were recorded, transcribed verbatim and analysis. There are seven participants taken by purposive sampling. Aged 25 to 55-years old and already treated at SP for at less two-times and more and even almost finished.

\section{B. Data Collection and Analysis}

Participants were interviewed at the SP while they were waiting for healing and at home. Before starting with interview, researchers made an agreement with the two of SP administration staff to gain general information and to have a link that connected the researchers to the participants. Bearing information in mind and noted, researchers than approach SP's patients to meet participants targeted. Once meet researchers than explaining the research aims and purpose. The authority of patients was priority. Patients that verbally agreed to participate in the study then signed an inform consent sheet that legally confirmed them as participant. Accordingly, collecting data by deep interviews were taken individually; several times depending on participants needs. All data taken from interview was recorded, transcribed and validated by re-checking to the participants. Thus valid data were than analyzed.

Data analysis method was adopted from Collaizi (1978) [10] as written below:

- Describing the phenomenon under study through trying to understand the phenomenon of patient's experience. As well as coping strategies they adopt through the study of literature. In addition, researchers were trying to dive in and immerse themselves in a state of participants experience taking alternative healing at SP.

- Transcribing data interviews to be able to describe the experience of patients with fractures who came to SP. Thus, collecting description of the phenomenon through the opinion of participants.

- Reading those data two to three times thoroughly until able to understand the experience of patients. Additionally reading the entire description of the phenomena that have been submitted by participants.
- Understanding the experiences of the participants, it then continued to read the entire transcript of the interview and select statements are significant and in accordance with the particular goals for analysis.

- Signify typed data through re-read the statement and try to find keywords that are the core of the statement.

- Studied every keyword then grouping them into categories. Followed by re-read the entire existing category, compare and looking for similarities between these categories, and eventually to group similar categories into themes.

- Passed through to the theme found over the data and wrote it into a description of the relevant experience of participants.

- Went back to the participants and asked participants to read the description of the study. This was done to determine whether the description that had been developed by researchers in accordance with the state of respondent's experienced.

- $\quad$ Analyzed data that has been obtained during validation to the participants, and put it in the final description to enable the readers recognize the experience of participants as they perceived during the fracture healing process at SP.

\section{RESULTS}

The participants of this research are described in Table 1. They are in the second and more visiting to SP, domicile in East Java province, Javanese and Moslem.

TABle 1. THE CHARACTERISTICS OF PARTICIPANTS

\begin{tabular}{|c|c|c|c|c|c|}
\hline Participants & Age & Sex & Employee statute & $\begin{array}{c}\text { Type of } \\
\text { fracture }\end{array}$ & Reason \\
\hline $\mathrm{Ad}$ & 26 & $\mathrm{M}$ & $\begin{array}{c}\text { Health-insurance } \\
\text { salesperson }\end{array}$ & $\begin{array}{c}\text { Left } \\
\text { Clavicle }\end{array}$ & $\begin{array}{c}\text { Traffic } \\
\text { accident }\end{array}$ \\
\hline $\mathrm{Tn}$ & 25 & $\mathrm{~F}$ & Teacher & $\begin{array}{c}\text { Left Tibia- } \\
\text { Fibula }\end{array}$ & $\begin{array}{c}\text { Traffic } \\
\text { accident }\end{array}$ \\
\hline $\mathrm{Ag}$ & 39 & $\mathrm{M}$ & $\begin{array}{c}\text { Provincial } \\
\text { Employee }\end{array}$ & Right Hip & $\begin{array}{c}\text { Traffic } \\
\text { accident }\end{array}$ \\
\hline $\mathrm{Dm}$ & 50 & $\mathrm{~F}$ & Housewife & Right Knee & Fall \\
\hline $\mathrm{Sv}$ & 44 & $\mathrm{~F}$ & $\begin{array}{c}\text { Shop Owner } \\
\text { Right } \\
\text { Carpus }\end{array}$ & Fall \\
\hline $\mathrm{Mc}$ & 28 & $\mathrm{M}$ & $\begin{array}{c}\text { Fishing Business } \\
\text { owner }\end{array}$ & $\begin{array}{c}\text { Lumbar } \\
\text { Fall }\end{array}$ & Fall \\
\hline Df & 55 & M & Civil servant & Right ankle & Ful \\
\hline
\end{tabular}

\section{A. Topic 1: Causes of fracture}

Almost half of participants had fracture caused by falls and traffic accidents.

\section{B. Topic 2: Time events}

A small part of a participant experienced more than a- year. Almost of them were suffered a closed fracture since less than 3 months ago. There was one of the participants experienced fracture since one week ago. Those participants were already getting treatment at the time of the interview was at their third 
visit. Although each visit always brought positive progress, i.e. the range of motion that extends and pain are reduced, but not denied that the pain was still present when the healer did massage. Overall, all those written above did not deter the participants to stop coming for treatment.

\section{Topic 3: Action taken directly after insiden}

Almost no participant went directly to the SP where was interview taken, at the time after the incident for healing. One participant went straight to the other SP. Most headed to the hospital. Less than half of them rushed to SP after less satisfied with the handling of service and they got suggestions to SP precisely by physician.

\section{Topic 4: Pain experiences during handling in therapy SP}

Almost all participants said the similar statement when they began therapy / massage as a part of fracture treatment by healer at SP. Starting from the pain of mild to severe. One participant said that he combined SP's treatment with physiotherapy at one of state hospital. This respondent stated a very significant progress of healing process. Pain was presents when the massage processed by the healer. However, pain can be reduced to the level of mild pain no longer after the massage finished.

\section{E. Topic 5: Coping of the patients}

Almost all the participants had positive responses with the treatment they got from SP. There were no statements from respondent that they would stop treatment process any time when they had no intention to the outcome.

\section{F. Topic 6: Pain management}

Medication such as painkillers oral was suggested by the healer. The healer informed the participant name of analgesic oral and topical to buy at medication store. In addition, the healer was also recommended some multivitamins to support bone union and encourage avoiding certain foods.

\section{G. Topic 7: Advice given by healer to other patients participants}

The first participant advised by the healer to come to physician first at the very beginning they arrived at SP. Participants thought that SP was advisable because it was not only solve the problem of physical but also psychological and or spiritual caused by fracture Almost of participants declared that the severity of a fracture should be to a medical first before to SP.

\section{DISCUSSION}

SP as an alternative for fracture healing was recommended by family, relatives and close friends. No one participant came to SP with her/his own initiative. Positive statement from the previous has become a strong motivation to make a final decision in regard fracture healing.

"This was not my first experience went to SP to get treatment for my clavicle; I had gone to another SP. It seemed I was an SP's adventure..hahahaha (laugh). I heard too many suggestions so I compared what my friend said and which one was the best based my personal views. Finally, this SP helped me much”. (Ad, 26-year-old with fracture left clavicle)

"My father knew well the father of the healer. I was around ten when I fell from Mango's tree and my father took me here and I was satisfied with the result. My leg was normal after that (he exposed her right leg), I had no difficulties. Even though not all my extended family agreed to go to this SP (for fracture healing, another family member went to another SP), but I am sure this one is the most suitable for me”. (Df, 55year-old with fracture left ankle)

The healer as the center of the healing process of fracture at an SP practiced a supernatural approach through massage which was perceived by participants. They believed that every healer at SP had that kind power.

"That was a magic power or something like that. In my religion (Islam), selected person may be given by Allah (God) that kind of ability; they were able to cure without medication. I heard the healer always start with du'a before and after doing massage." (Tn 25-year-old, fracture left tibia-fibula)

They expressed that during this massage process, participants experience a pain sensation. To reduce a pain, the healer recommended name of painkiller oral and or topical.

"You must know this kind of analgesic? (she showed a blister of analgesic to reduce pain), feel free to ask all patients here (at SP), they should bring the similar thing." (Sy, 44-yearold with fracture right Carpus)

"Look! This ointment is burning my skin (showing his right hip). The healer recommended me to have this. I bought from medicine store. It is limited, so the price was a bit expensive." (Ag, 39-year-old, fracture right hip)

Although they did not exactly know the series of visiting's need to have a bone recovery, all participants said that they want to get well soon so they follow what the healer suggested.

"This is my third visit, I heard for this type of fracture needs around six or more but it less than ten times....(silent) but I don't think so, so far I feel much better than my first visit, and I feel everything is going well by day." (Mc, 28-year-old, fracture lumbar)

The healer sometimes informed the bone healing process after massage finished. Everything come from the healer during the healing process were perceived in a positive manner by participants. Implicit in the results of interviews with sources of hope and advice conveyed such as there are others who suffered the same fracture.

"Three days ago, after she finished (the healer) with massage, she told me that the bone was joined well. I was very grateful hear that. I wish (now) she will inform me that the bone conjunctions were strengthening than before. My fracture is more difficult to be healed compared to others (because of that) I was suggested to immobile this knee. At home my husband and sons help me for my daily needs." (Dm, 50-yearold, fracture right knee) 
Not merely because of lack of funds for treatment to a medical treatment (Table 1 as written above, showed that all participant are financially independent), but they come to SP for various considerations and reasons.

"I feel so relax here than a general hospital. Two years ago, my daughter fell from her motorbike and her friends took her to a hospital. My wife and I were very stressed with emergency ward situation. I asked to the surgeon how the fracture was and he said that it did not need any surgery, so I did not go back to hospital after that. I brought my daughter here." (Ag, 39-year-old, a provincial employees)

Family, relatives and close friends who suggested them for SP treatment were fully attention and follow the result of every visit. Further, during the waiting time for healing, most all participants talked to each and shared their experience. Participant perceived that situation was not found in any hospital. This has been stated by [12] that perception is the major of the social aspect, so that people freed from using services of an alternative based on their personal perspectives. In addition, treatment by a healer at SP as perceived by the public; works, and partly states that cost was not relevant. Almost of the respondents know their suitability and herb used techniques. Massage techniques and the sequence of respondents believed the herb is very useful in fracture healing.

Additionally, based on background of participants; demographics, economic, religion and culture, and economic, they are vary from middle to high economic level, Moslem, and Javanese. Further, even though the coverage of health insurance provided by Indonesia's government was fully funded for any hospital service, it does not replace the existence of SP.

Generally, participants are believed in the medical services, but they are also searched for any alternative treatment that did not only focus on the problem of physic as they perceived. [2] stated that negative perception makes public attitudes towards complementary medicine was also negative. This has been expressed by participant that SP healer was able to provide a sense of confidence that they will be recovered. The spiritual characteristic was a basic that bridge the participant's expectation to the bone recovery. This was the less they got when going to the medical service.

\section{CONCLUSION AND RECOMMENDATION}

It can be concluded that participants put safe and comfort on the priority when they decide to get help for fracture. Pain which is commonly expressed by people with fracture decreased effectively when painkiller combined with safe and comfortable atmosphere work in balance. At SP along the healing process, people with fracture experienced a holistic care that combined a multiple approaches of culture, cure, and care. SP as an alternative for fracture healing has been welldeveloped from generation to generation.
The value of SP as an alternative for fracture healing has been widely spread in any tribe and level of society in Indonesia. This study was taken in rural area close to Surabaya as a referral for health service for the Eastern of Indonesia Region. Further study is needed to be explored by considering cultural values and ethical practices.

\section{REFERENCES}

[1] Smeltzer S., Bare B., HInkle J., Cheever K. Brunner \& Suddarth's Textbook Of Medical-Surgical Nursing (Vol. 12th). China: Lippincott Williams \& Wilkins; 2010.

[2] Ignatavicius, D. D., Workman ML. Medical-Surgical Nursing; Patient-Centered Collaborative Care (Vol. 7th). United States: Elsivier Saunders; 2013.

[3] Pricilla L. Medical-Surgical Nursing; Critical Thinking For Person-Centered Care (Vol. 2nd). China: Kickass Torrents; 2014.

[4] Menteri Kesehatan. Kepmenkes 116 / Menkes / SK / VIII / 2003. Indonesia; 2003.

[5] Kementerian Kesehatan RI. PROFIL KESEHATAN INDONESIA. Jakarta; 2014.

[6] Sintiasari R. Gambaran Tingkat Pengetahuan Penderita Tentang Penanganan Dan Penyembuhan Patah Tulang Di Pengobatan Tradisional Sangkal Putung Fatimah Sidoarjo. Stikes William Booth, Surabaya; 2013.

[7] Aries MJH, Joosten H, Wegdam HHJ, Van Der Geest S. Fracture treatment by bonesetters in central Ghana: patients explain their choices and experiences. Trop Med Int Heal [Internet]. 2007 Apr 16 [cited 2017 Jun 19];12(4):564-74. Available from: http://doi.wiley.com/10.1111/j.1365-3156.2007.01822.x

[8] Mirhadi S, Ashwood N, Karagkevrekis B. Factors influencing fracture healing. Trauma [Internet]. 2013;15(2):140-55. Available from: http://journals.sagepub.com/doi/pdf/10.1177/146040861 3486571

[9] Burns, N. P. D. \& Grove SK. Understanding Nursing Research: Building An Evidence-Based Practice. Maryland Heights, Mo. London: Saunders; 2011.

[10] Shosha GA. Employment Of Colaizzi's Strategy In Descriptive Phenomenology: A Reflection Of A Researcher. Eur Sci J Novemb Ed [Internet]. 8(27):1857-7881. Available from: http://eujournal.org/index.php/esj/article/viewFile/588/65 7

[11] Polit D, Beck C. Nursing Research: Generating And Assessing Evidence For Nursing Practice. 8th ed. Philadelphia: Lippincott Williams \& Wilkins, A Wolters Kliwer Business,; 2008.

[12] Van Manen M. Researching lived experience: human science for an action sensitive pedagogy. Ontario: The Althouse Press; 1990. 